\title{
Quantitative estimation of interferon-gamma levels among Egyptian polytransfused haematology cases
}

M.N. Roshdy, R.A. Harfoush, ${ }^{7}$ N.A. Hamed ${ }^{2}$ and M.G. Morsi ${ }^{1}$

$$
\begin{aligned}
& \text { تقدير كمي لمستويات الإنترفيرون - غاما بين حالات مصابة بأمر اض الدم تلقَّتْ نقل دم متكرراً في مصر }
\end{aligned}
$$

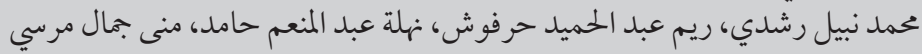

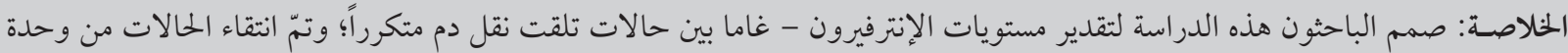

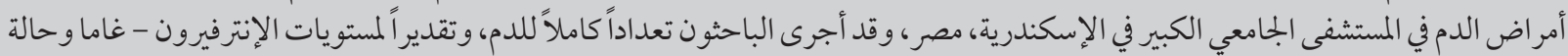

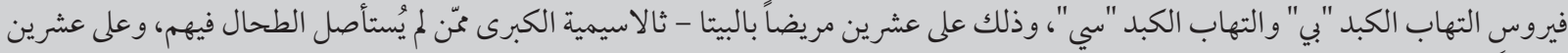

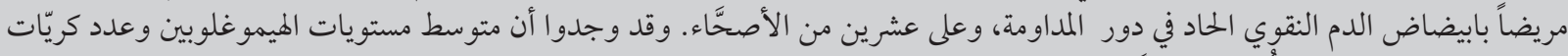

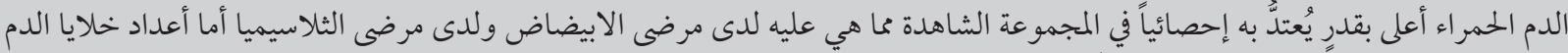

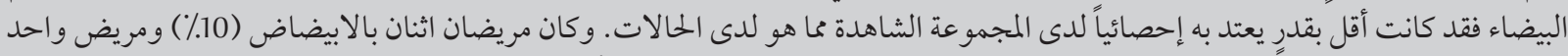

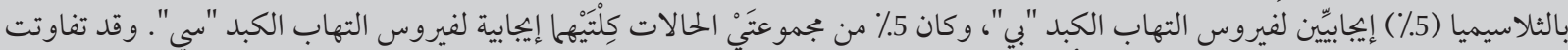

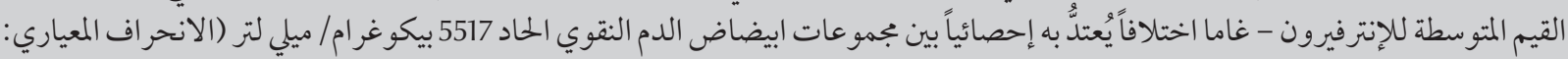

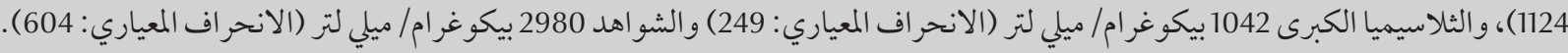

ABSTRACT This study was designed to estimate interferon-gamma (INF- $\gamma$ ) levels among polytransfused haematology cases. Cases were selected from the haematology unit of Alexandria main university hospital, Egypt. Complete blood counts, estimation of INF- $\gamma$ and hepatitis B and C virus (HBV and HCV) status were conducted on 20 unsplenectomized patients with $\beta$-thalassaemia major and 20 patients with acute myeloid leukaemia (AML) in the maintenance phase and 20 healthy subjects. Mean haemoglobin levels and red blood cell counts were significantly higher in the control group than the AML and thalassaemia groups, while white blood cell counts were significantly lower in the control group than the case groups. Two AML patients (10\%) and 1 thalassaemia patient (5\%) were HBV-positive, while 5\% of both case groups were HCV-positive. Mean values of INF- $\gamma$ were significantly different between AML, thalassaemia major and control groups: 5517 (SD 1142) pg/mL, 1024 (SD 249) $\mathrm{pg} / \mathrm{mL}$ and 2980 (SD 604) pg/mL respectively.

Estimation quantitative des taux de gamma-interféron chez des Égyptiens polytransfusés en hématologie

RÉSUMÉ La présente étude visait à estimer les taux d'interféron-gamma chez des patients atteints d'affections hématologiques polytransfusés. Des cas ont été sélectionnés dans le service d'hématologie du principal hôpital universitaired'Alexandrie(Égypte). Unenumérationformulesanguine, uneestimation destauxd'interféron-gamma etdustatutdel'infection parlesvirus del'hépatite BetC ontétémenéeschez20 patientsnonsplénectomisésatteints de $\beta$-thalassémie majeure et chez 20 patients atteints d'une leucémie myéloïde aiguë en phase d'entretien ainsi que chez 20 sujets sains. Les taux d'hémoglobine moyens et la numération érythrocytaire étaient nettement plus élevés dans le groupe témoin que dans les groupes atteints de leucémie myéloïde aiguë ou de thalassémie, tandis que la numération leucocytaire était très inférieure dans le groupe témoin par rapport à celle des autres groupes. Deux patients atteints de leucémie myéloïde aiguë (10\%) et un patient souffrant de thalassémie (5\%) étaient positifs pour le virus de l'hépatite B, et $5 \%$ des cas des deux groupes affectés étaient positifs pour le virus de l'hépatite $C$. Les valeurs moyennes d'interféron-gamma étaient très différentes entre les groupes atteints de leucémie myéloïde aiguë, de thalassémie majeure et le groupe témoin : 5517 pg/ml (ET 1142), 1024 pg/ml (ET 249) et 2980 pg/ml (ET 604) respectivement. 


\section{Introduction}

Interferon-gamma (IFN- $\gamma$ ) is a cytokine that is critical for innate and adaptive immunity against viral and intracellular bacterial infections and for tumour control $[1,2]$. Changes in immune response are believed to be the cause of morbidity and mortality in infections associated with thalassaemia major (beta-thalassaemia) [3]. A role for IFN- $\gamma$ together with other cytokines have been claimed previously in the immunopathogenesis of beta-thalassaemia [4]. Defects in counts or altered functions of a wide range of peripheral bloodleukocytes and anomalies of serum level of cytokines have been reported $[5,6]$. Proposed factors involved in these anomalies are: iron overload, repeated foreign antigen exposure at the time of blood transfusion and the use of chelating agent (deferoxamine). Consequently these patients suffer from infectious episodes due to immune alterations [7]

Recently, an additional role for IFN $-\gamma$ has been identified in preventing primary and transplanted tumours from developing. IFN- $\gamma$ can be released in the presence of native human acute myeloid leukaemia (AML) cells and affect AML cell proliferation, regulation of apoptosis and the balance between pro- and anti-angiogenic chemokine release. Immunotherapy targeting T-cells is now considered a possible strategy in treating AML, and IFN- $\gamma$ release may then contribute to the antileukaemic effect [8]. IFN- $\gamma$ promotes the host response to tumours, although the mechanism by which this cytokine achieves its effects are debatable [9].

Most thalassaemia patients with more severe grades of anaemia need regular blood transfusion to facilitate growth. Patients with malignant diseases such as acute leukaemias also often require repeated red blood cell (RBC) and platelet transfusions [10]. This study in Alexandria, Egypt was designed to estimate INF- $\gamma$ levels among polytransfused haematology cases with $\beta$-thalassaemia major and AML as a first step towards assessing the potential use of immunotherapy in these diseases.

\section{Methods}

\section{Sample}

The study was conducted in 2010 on 40 polytransfused haematology cases suffering from transfusion-dependent thalassaemia and leukaemias. Cases were selected from patients attending Alexandria main university hospital and based on clinical and laboratory criteria. All were non-splenectomized, before receiving any medication, not diabetic or hypertensive and of comparable age and sex. Twenty age- and sex-matched healthy subjects recruited from heath care personnel served as controls. Patients with diabetes mellitus, hypertension, hepatic and renal failure, signs of infection (e.g. fever) and positive for HIV were excluded. The subjects of the current study were grouped for analysis into: 20 AML cases in the maintenance phase of treatment (i.e. 3 months after stopping chemotherapy and blood transfusion) (group 1); 20 thalassaemia major cases (non-splenectomized) (group 2) and 20 healthy controls (group 3).

\section{Data collection}

Every patient was subjected to the following: history taking, full clinical assessment and abdominal ultrasound. Both patients and controls were subjected to: complete blood count (CBC), liver function tests [alanine aminotransferase (ALT), aspartate aminotransferase (AST) and serum bilirubin], serum ferritin levels (for thalassaemic patients) and bone marrow examination (for leukaemia patients).

\section{Microbiological and immunological} tests

Estimation of INF- $\gamma$ levels were done by isolation of peripheral blood mononuclear cells from heparinized venous blood by Ficoll-Hypaque density layer centrifugation (Sigma Aldrich) and cultured at $2 \times 105$ cells per $500 \mu \mathrm{L}$ in Roswell Park Memorial Institute medium 1640 (Sigma Aldrich) supplemented with antibiotics and 5\% fetal calf serum (Sigma Aldrich). For stimulation, $5 \mu \mathrm{g} / \mathrm{mL}$ phytohaemagglutinin mitogen (Wellcome Diagnostics) was used. Incubation of cultures was performed at $37^{\circ} \mathrm{C}$ in a humidified atmosphere of $5 \% \mathrm{CO}_{2}$.

After 48 hours incubation, culture supernates were collected from each tube and stored at $-20^{\circ} \mathrm{C}$ to be assayed using commercial ELISA kits (RayBio human IFN- $\gamma$ ) $[11,12]$. For HBV surface antigen (HBsAg) (Enzygnost HBsAg 6.0, Behring) and HCV antibodies (HCVAb) (Ortho HCV 3.0, Ortho-Clinical Diagnostics) 3rd generation ELISA were followed according to manufacturers' instructions $[13,14]$. Tests for HBsAg and HCVAb are routinely done to all subjects (cases and controls). Negative cases were taken as controls in the immunological tests.

\section{Reference levels}

The cut-off absorbance values were $\geq$ $0.750 \mathrm{~nm}$ for HBsAg and $\geq 0.620 \mathrm{~nm}$ for $\mathrm{HCV}$. Using the Second International Standard for HBsAg (NIBSC code: 00/588), the analytical sensitivity of the test system was determined at $<0.032$ $\mathrm{IU} / \mathrm{mL}$. For the HCV test system with enhanced sample addition verification, sensitivity and specificity were around 96.6\% compared with RT-PCR (real time-polymerase chain reaction) for HCV levels in sera and Chiron recombinant immunoblot assay for HCV antibodies as confirmatory tests. For INF- $\gamma$ we used a standard curve to detect IFN at the subnanogram level ( $\geq 100 \mathrm{pg}$ ).

\section{Data analysis}

Descriptive statistics included ranges, frequencies and percentages, median, mean and standard deviation (SD). Comparisons of numerical variables between the study groups were made using the Mann-Whitney U-test for independent samples. To compare 
categorical data, the chi-squared test was used, or Fisher exact test when the expected frequencies were $<5$. Accuracy was represented using sensitivity and specificity. Receiver operator characteristic analysis was used to determine the optimum cut-off value for the studied tests. Correlations between variables were tested using the Spearman rank correlation coefficient equation for non-normal variables $(r)$. $P$-values $<0.05$ were considered statistically significant. Normality of data was checked by the Kolmogorov-Smirnov test. Two-tailed tests were used where appropriate. All statistical calculations were performed using the computer programs Microsoft Excel 2007 and SPSS, version 15 for Windows.

\section{Results}

\section{Laboratory findings}

Laboratory findings for the 3 groups as shown in Table 1. The mean haemoglobin levels were 9.60 (SD 1.26) $\mathrm{g} / \mathrm{dL}, 10.1$ (SD 1.65) g/dL and 14.1 $(\mathrm{SD} 1.98) \mathrm{g} / \mathrm{dL}$ for AML, thalassaemia major and control groups respectively. The levels in the control group were significantly higher than both the AML and thalassaemia groups $(P<0.001)$. WBC counts ranged between 7.70 (SD $1.85) \times 103 / \mu \mathrm{L}, 7.22(\mathrm{SD} 2.08) \times 103 /$ $\mu \mathrm{L}$ and $6.13(\mathrm{SD} 1.99) \times 103 / \mu \mathrm{L}$ for AML, thalassaemia major and control groups respectively, and this was significant comparing the controls with both the AML and thalassaemia groups (P
$<0.001$ ). RBC counts were 3.12 (SD $0.98) \times 106 / \mu \mathrm{L}, 2.98($ SD 1.33) $\times 106 /$ $\mu \mathrm{L}$ and $4.20(\mathrm{SD} 1.01) \times 106 / \mu \mathrm{L}$ for AML, thalassaemia major and control groups respectively. Control levels were significantly higher than the AML and thalassaemia groups $(\mathrm{P}=0.025)$.

\section{Serological data}

Table 2 shows that HBsAg was detected in 2/20 (10\%) of AML patients and $1 / 20$ (5\%) of thalassaemia patients, while (HCVAb) were found in $1 / 20$ (5\%) of both AML and thalassaemia groups. There were no significant differences between the 2 studied groups regarding the serological data. The controls were negative in both tests.

\section{INF- $\gamma$ results}

Table 1 also shows the comparison between INF- $\gamma$ levels among the 3 studied groups. The mean values of INF- $\gamma$ were 5517 (SD 1142) pg/mL, 1024 (SD 249) $\mathrm{pg} / \mathrm{mL}$ and 2980 (SD 604) pg/ $\mathrm{mL}$ for AML, thalassaemia major and control groups respectively. The differences between the 3 groups were statistically highly significant. The AML group had the highest values compared with the other 2 groups, while the control group was still significantly higher than the thalassaemia group $(\mathrm{P}=0.013)$.

\section{Discussion}

A major cause of morbidity and mortality in thalassaemia patients is infections, assumed to be the result of immunological changes [3]. There is growing evidence suggesting that some cytokines, including interferon-gamma (IFN- $\gamma$ ), play an important role in the pathogenesis of thalassaemia [4]. Previous studies have investigated haematological and immunological abnormalities in patients with beta-thalassaemia. Our haematology findings agree with Shfik et al., who found that the mean level of RBC counts in polytransfused $\beta$-thalassaemia patients with and without splenectomy [3.76 (SD 0.67) and $3.04($ SD 0.80$) \times 106$ cells $/ \mathrm{mL}$ respectively] were significantly lower compared with a control group [6]. The mean RBC count in our unsplenectomized $\beta$-thalassaemia major patients $[2.98(\mathrm{SD} 1.33) \times 106 / \mu \mathrm{L})]$ was significantly lower than the control group $[4.20(\mathrm{SD} 1.01) \times 106 / \mu \mathrm{L}]$. The mean haemoglobin concentrations in Shfik et al.'s study were significantly reduced in unsplenectomized $\beta$-thalassaemia patients $[6.53(\mathrm{SD} 0.18) \mathrm{g} / \mathrm{dL}]$ compared with the control group. In our study the mean haemoglobin level was 10.1 $(S D 1.65) \mathrm{g} / \mathrm{dL}$ in the $\beta$-thalassaemia group and this was significantly lower than the control group [14.1 (SD 1.98) $\mathrm{g} / \mathrm{dL}$ ]. In the study by Shfik et al., there were no statistically significant differences in total leukocyte count between the studied groups, apart from a slight but statistically insignificant increase in $\beta$-thalassaemia patients with splenectomy [6]. We found higher mean WBC counts in the $\beta$-thalassaemia

\begin{tabular}{|c|c|c|c|c|c|}
\hline \multirow[t]{2}{*}{ Variable } & $\begin{array}{c}\text { AML } \\
\text { Group } 1 \\
(n=20)\end{array}$ & $\begin{array}{l}\text { Thalassaemia major } \\
\text { Group } 2 \\
(n=20)\end{array}$ & $\begin{array}{l}\text { Control } \\
\text { Group } 3 \\
(n=20)\end{array}$ & $\begin{array}{c}F \text {-value } \\
\text { (ANOVA) }\end{array}$ & $P$-value \\
\hline & Mean (SD) & Mean (SD) & Mean (SD) & & \\
\hline Haemoglobin (g/dL) & $9.60(1.26)$ & $10.1(1.65)$ & $14.1(1.98)^{a, b}$ & 11.4 & $<0.001$ \\
\hline White blood cells $\left(\times 10^{3} / \mu \mathrm{L}\right)$ & $7.70(1.85)$ & $7.22(2.08)$ & $6.13(1.99)^{a, b}$ & 3.98 & $<0.001$ \\
\hline Red blood cells $\left(\times 10^{6} / \mu \mathrm{L}\right)$ & $3.12(0.98)$ & $2.98(1.33)$ & $4.20(1.01)^{\mathrm{a}, \mathrm{b}}$ & 3.99 & 0.025 \\
\hline INF- $\gamma(p g / m L)$ & $5517(1142)^{c}$ & $1024(249)$ & $2980(604)^{a, b}$ & 12.7 & 0.013 \\
\hline
\end{tabular}

${ }^{a} P<0.05$ group 3 versus $7 ;{ }^{b} P<0.05$ group 3 versus $2 ;{ }^{c} P<0.05$ group 1 versus 2 .

$S D=$ standard deviation. 


\begin{tabular}{|c|c|c|c|c|c|c|c|}
\hline \multirow[t]{2}{*}{ Variable } & \multicolumn{2}{|c|}{$\begin{array}{c}\text { AML } \\
\text { Group 1 } \\
(n=20)\end{array}$} & \multicolumn{2}{|c|}{$\begin{array}{l}\text { Thalassaemia major } \\
\text { Group } 2 \\
(n=20)\end{array}$} & \multicolumn{2}{|c|}{$\begin{array}{l}\text { Control } \\
\text { Group } 3 \\
(n=20)\end{array}$} & \multirow[t]{2}{*}{$P$-value } \\
\hline & No. & $\%$ & No. & $\%$ & No. & $\%$ & \\
\hline HBsAg +ve & 2 & 10 & 1 & 5 & 0 & 0 & 0.103 \\
\hline HCVAb +ve & 1 & 5 & 1 & 5 & 0 & 0 & 0.225 \\
\hline
\end{tabular}

HbsAg= hepatitis B virus surface antigen; HCVAb = hepatitis $C$ virus antibody.

major patients $[7.70($ SD 1.85) $\times 103 /$ $\mu \mathrm{L}$ ] than controls 6.13 (SD 1.99) $\times 103 / \mu \mathrm{L}]$, and an even higher level in the AML group [9.60 (SD 1.26)]. This may be that our cases were nonsplenectomized and were not suffering from cardiac, hepatic, renal, diabetic or hypertensive problems.

Mean RBC counts in AML patients were also significantly lower than in the control group. The haemoglobin level of AML patients was slightly lower than the $\beta$-thalassaemia patients and was also significantly lower than that of the controls.

In agreement with our results, Shfik et al. found no statistical significant differences between the 2 groups of patients with and without splenectomy regarding clinical data [6]. We detected HBsAg in 2 AML patients and 1 thalassaemia patient, while HCVAb were found in 1 case in both groups. This may be explained by good viral screening in our blood banks before blood transfusion.
Our results showed that mean INF- $\gamma$ values were 5517 (SD 1142) pg/mL, 1024 (SD 249) pg/mL and 2980 (SD 604) pg/mL for AML, thalassaemia major and control groups respectively. The AML group INF- $\gamma$ level was significantly higher than in the other groups, while the control group level was significantly higher than in the thalassaemia group. In agreement with our results, Bruserud et al. discussed the influence of disease status, chemotherapy and complicating infections on serum levels of cytokines and soluble adhesion molecules among transfused cases in acute leukaemia patients [15]. They demonstrated increased serum levels of both INF- $\gamma$ and INF- $\gamma$ antagonists in acute leukaemia patients with complicating bacterial infections during chemotherapy-induced cytopenia. Serum levels of selection adhesion molecules were decreased during bacterial infections in leukopenic patients compared with healthy individuals. On the other hand, Gharagozloo et al. studied the immunological abnormalities of
Iranian $\beta$-thalassaemia major patients. Their results showed that patients with $\beta$-thalassaemia had significantly higher absolute lymphocyte counts compared with the control group. T-cell proliferation and IL-2, IFN- $\gamma$ and IL-4 production were suppressed in patients compared with controls [16]. These findings may be explained by infections associated with repeated blood transfusion. Furthermore chemotherapy may alter the blood picture and the levels of cytokines studied.

\section{Conclusions}

Our data demonstrated that INF- $\gamma$ levels were high among AML, control and thalassaemia groups respectively. HBsAg were found in $10 \%$ and $5 \%$ of AML and thalassaemia groups, while HCVAb were found in 5\% of both AML and thalassaemia groups. Further studies are needed towards possible use of immunotherapy in these diseases.

Competing interests: None declared.

\section{References}

1. Fensterl V, Sen GC. Interferons and viral infections. BioFactors (Oxford, England), 2009, 35:14-20.

2. Schroder K et al. Interferon-gamma: an overview of signals, mechanisms and functions. Journal of Leukocyte Biology, 2004, 75:163-189.

3. El-Beshlawy A, Youssry I. Prevention of hemoglobinopathies in Egypt. Hemoglobin, 2009, 33(Suppl. 1):S14-S20.

4. Moshtaghi-Kashanian GR et al. Splenectomy changes the pattern of cytokine production in beta-thalassemic patients. Cytokine, 2006, 35:253-257.

5. Lombardi G et al. Serum levels of cytokines and soluble antigens in polytransfused patients with beta-thalassemia major: relationship to immune status. Haematologica, 1994, 79:406-412.
6. Shfik $\mathrm{M}$ et al. Serum levels of cytokines in poly-transfused patients with beta-thalassemia major: relationship to splenectomy. Journal of American Science, 2011, 10:20-30.

7. Consolini $\mathrm{R}$ et al. Immunological evaluation of patients with beta-thalassemia major. Acta Haematologica, 2001, 105:7-12.

8. Ersvaer $\mathrm{E}$ et al. Effects of interferon gamma on native human acute myelogenous leukemia cells. Cancer Immunology and Immunotherapy, 2007, 56(1):13-24.

9. Ikeda H, Old LJ, Schreiber RD. The roles of IFN $\gamma$ in protection against tumor development and cancer immunoediting. $\mathrm{Cy}$ tokine and Growth Factor Reviews, 2002, 13:95-109.

10. Acute leukemias in adult. In: Maza GG, ed. Manual of clinical hematology, 3rd ed. Philadelphia, Lippincott, Williams and Wilkins 2002, 20:214-227. 
11. Morsi MG, Atta HY, Rabie AK. Comparative study of different test systems of measuring cytokine production among tuberculous and healthy persons. Egyptian Journal of Immunology, 1998, 5:153-162.

12. O'Neill LAJ, Bowie A. Interleukin protocols. Methods in molecular medicine series, Volume 60. New York, Springer, 2001, 60:3-15.

13. Valentine-Thon $\mathrm{E}$ et al. European proficiency testing program for molecular detection and quantitation of hepatitis B virus DNA. Journal of Clinical Microbiology, 2001, 39:4407-4412.
14. Tobler LH et al. Impact of HCV 3.0 EIA relative to HCV 2.0 EIA on blood-donor screening. Transfusion, 2005, 43:1452-1459.

15. Bruserud $\varnothing$ et al. Serum levels of adhesion molecules and cytokines in patients with acute leukaemia. Leukemia and Lymphoma, 1996, 23:423-430.

16. Gharagozloo M, Karimi M, Amirghofran Z. Double-faced cellmediated immunity in beta-thalassemia major: stimulated phenotype versus suppressed activity. Annals of Hematology, 2009, 88:21-27. 